\title{
The Pragmatic Maxim and Four Classical Pragmatists
}

\author{
Liang Meng \\ North China Electric Power University
}

\begin{abstract}
This essay explores the issue of what makes a pragmatist. It centers on the pragmatic maxim of Charles Sanders Peirce. Although Peirce deliberately coined the word "Pragmaticism” to express his disapproval of James's pragmatism, his pragmatic maxim has become the touchstone of a pragmatist, so much so that, to be a pragmatist, one must endorse the pragmatic maxim, notwithstanding the fact that the pragmatic maxim is open to various interpretations, as shown in the four classical pragmatists, Peirce, James, Dewey, and Mead. Their different interpretations of the pragmatic maxim are examined successively so as to offer a panoramic view of the pragmatic maxim and its significant role in constituting a pragmatist.
\end{abstract}

Keywords: Peirce, the pragmatic maxim, pragmatist, James, Dewey, Mead

\section{Introduction}

What is pragmatism? Tom Burke clarifies long-standing misunderstandings about pragmatism in the following passage:

First of all, pragmatism is not a single philosophy. There is no single pragmatist epistemology, no single pragmatist metaphysics. More particularly, there is not just one pragmatist theory of truth. Rather, pragmatism is a style or way of doing philosophy. As such, it allows a variety of views on just about any philosophical topic. (Burke 2007)

In a word, pragmatists may hold different views on various philosophical topics, including metaphysical ones. Although they usually reject traditional metaphysics, pragmatists can do metaphysics, in a pragmatic way of course. (Much has been written about William James's metaphysics and John Dewey's metaphysics respectively.)

This essay, however, is not concerned with how some, if not most, pragmatists do metaphysics, but with what makes a pragmatist. Pragmatism emerges in James's book Pragmatism as six things: a philosophical temperament, a theory of truth, a theory of meaning, a holistic account of knowledge, a metaphysical view, and a method of resolving philosophical disputes (Goodman 2006). While a theory of truth, a theory of meaning, a holistic account of knowledge, and a metaphysical view cannot essentially distinguish a pragmatist from other philosophers, as Burke has convincingly proved, a philosophical temperament and a method of resolving metaphysical disputes deserve special treatment. James classifies philosophers according to their temperaments (Goodman 2006). The pragmatist, in James's view, is the mediator between the extremes of "tough-minded" and "tender-minded," someone, like James himself, with "scientific loyalty to facts," but also "the old confidence in human values and the resultant spontaneity, whether of the religious or romantic type" (Goodman 2006). This temperamental distinction, like the other four distinctions mentioned above, is not sharp enough to

Liang Meng, Ph.D., Department of English, North China Electric Power University, China; main research field: Theory of Knowledge. 
give people a clear idea of the difference between, say, a pragmatist and a metaphysical positivist. Here a question arises: What counts as the distinctive trait of a pragmatist? The answer, I would claim, lies in James's assertion that pragmatism is a method of resolving metaphysical disputes (James 2000, 194). Obviously, this assertion, which aims at avoiding metaphysical confusion, echoes the pragmatic maxim of Charles Sanders Peirce. William James is not alone in making statements related to Peirce's pragmatic maxim. John Dewey and George Herbert Mead also “adhere to some version” (Burke 2007) of the pragmatic maxim that Peirce advanced in relation to his Pragmaticism.

Although Peirce deliberately coined the word "Pragmaticism” to express his disapproval of James's pragmatism, his pragmatic maxim has become the touchstone of a pragmatist, so much so that, to be a pragmatist, one must essentially and substantively endorse the pragmatic maxim (Burke 2007), notwithstanding the fact that the pragmatic maxim is open to various interpretations, as shown in the four classical pragmatists, Peirce, James, Dewey and Mead.

I shall examine their different interpretations of the pragmatic maxim successively so that I could offer a panoramic view of the pragmatic maxim and its significant role in constituting a pragmatist.

\section{Peirce and the Pragmatic Maxim}

First of all, I would like to draw attention to the origin of the pragmatic maxim. In "How to Make Our Ideas Clear,” Peirce (2000) says: “Consider what effects, which might conceivably have practical bearings, we conceive the object of our conception to have. Then our conception of these effects is the whole of our conception of the object" (82). This statement, which sums up the action-contingent consequences of the object (Scheffler 1974, 78), is Peirce's pragmatic maxim. Peirce's (2000) pragmatic maxim is meant to be the rule for attaining the third grade of clearness of apprehension (82). What, then, are the first two grades of clearness in the eyes of Peirce? The first grade of clearness is familiarity with an idea of reality (Peirce 2000, 77) and the second grade of clearness the idea's abstract definition (Peirce 2000, 85). Neither, however, can make the idea of reality perfectly clear (Peirce 2000, 85). Therefore, it is necessary to attain the third grade of clearness, which requires us to introduce action and effects into our idea of reality, the reality of an object for example. To illustrate what the third grade of clearness is, let us consider our conception of hardness as represented by the adjective "hard," which is understood to be our conception of all those sensible effects resulting from practical operations upon hard things (Scheffler 1974, 78). Our conception of hardness is thus clarified with reference to action and effects. To recapitulate, Peirce's pragmatic maxim is not so much concerned with whether our ideas are true or false as with how to make the meanings of our ideas clear. Therefore, the pragmatic maxim is confined to the theory of meaning and has nothing to do with the theory of truth.

Peirce's pragmatic maxim is intended as an attack on rationalist conceptions of meaning, which is part of Peirce's rejection of metaphysics (Scheffler 1974, 76). Unlike Peirce, James takes a reconciliatory stance toward metaphysics.

\section{James and the Pragmatic Maxim}

In “What Pragmatism Means," James’s (2000) interpretation of Peirce's pragmatic maxim is preceded by a discussion of the pragmatic method of resolving the metaphysical dispute about a human being going round a squirrel going round a tree (193). A metaphysical question is raised: "Does the man go round the squirrel or not?” (James 2000, 193) The pragmatic method of settling this dispute is as follows: Which party is right 
depends on what one practically means by going round the squirrel. If one means by going round the squirrel that the man goes north, east, south, west, and north of the squirrel, then the man goes around the squirrel; if one means being in front of the squirrel, on its right, behind it, on its left and in front of it successively, then the man fails to go round the squirrel. That is to say, once the practical meaning of our conception of the object is determined, there is no occasion for dispute. In other words, the practical effects that the object involves clarify our conception of the object. James's story of the squirrel seems to be recounted in the vein of Peirce's pragmatic maxim.

While endorsing Peirce's pragmatic maxim, however, James also twisted it (Burke 2007). Peirce, as I have mentioned before, coined the word "Pragmaticism" to distance his philosophy from James’s Pragmatism, which, Peirce would say, is a misinterpretation of his pragmatic maxim.

How, then, does James interpret Peirce's pragmatic maxim? Having told the story of the squirrel, James proceeds to define pragmatism. The term, derivative from a Greek word, means action, from which the words "practice" and "practical" come (James 2000, 194). It was first introduced into philosophy by Peirce in 1878 (James 2000, 194). In the article entitled "How to Make Our Ideas Clear” published that year, Peirce, "after pointing out that our beliefs are really rules for action, said that, to develop a thought's meaning, we need only determine what conduct it is fitted to produce: That conduct is for us its sole significance" (James 2000, 194). Please note that James uses the word "sole" that Peirce would not use. I tend to think that this word makes all the difference. Before discussing this word, it is necessary to make a distinction between meaning and significance, which, though usually synonymous, have contextual differences here. While meaning is the message that is expressed by the thought, significance is the significance of the existence of the thought. If the significance of the existence of the thought only lies in the possibility that this thought can produce conduct, then it would be meaningless to talk about the thought in logic. James's overemphasis on conduct, which leads him to blur the boundary between the theory of truth and the theory of meaning, would be unacceptable to Peirce, who is a first-class logician and mathematician and as such would argue that the significance of the existence of a concept is independent of conduct, though conduct may help clarify the meaning of this concept.

That said, let us now return to James's essay. James (2000) continues: “And the tangible fact at the root of all our thought-distinctions, however subtle, is that there is no one of them so fine as to consist in anything but a possible difference of practice” (194). Here again we see James's emphasis on conduct or practice: A possible difference of practice, which is finer than any thought-distinctions, is at the root of all our thought-distinctions. Following this line of thinking, we could draw the conclusion that, if two different thoughts produce no difference of practice, they are practically the same thing and all dispute about them is idle (James 2000, 194), and that if two similar thoughts produce a difference of practice, they are practically different. Clearly, James seems to confer a fundamental role on practice in his world of pure experience whereas Peirce would subject practice to the needs of thought-distinctions.

After stressing the importance of conduct, James (2000) begins to talk about Peirce's association of effects with our conception of an object:

To attain perfect clearness in our thoughts of an object, then, we need only consider what conceivable effects of a practical kind the object may involve-what sensations we are to expect from it, and what reactions we must prepare. Our conception of these effects, whether immediate or remote, is then for us the whole of our conception of the object, so far as that conception has positive significance at all. (194) 
There is no doubt that James attempts to make a truthful representation of Peirce's pragmatic maxim. He embraces the third grade of clearness proposed by Peirce. Moreover, he adopts the collective pronouns "we" and "our" that Peirce uses and is wont to use. Please remember that while James's pragmatism revolves around the experience of an individual, Peirce's pragmaticism deals with the experience of a community, whether this community is that of scientists or of ordinary people, or of scientists and ordinary people combined.

This difference, so far as the passage quoted is concerned, involves a question: How would James and Peirce achieve clearness in conception of an object respectively? They do not seem to address this question explicitly, but there is good reason to assume that James's position on this issue would be that to achieve clearness of ideas does not require the collective action of a community, though James would not deny that the collective action of this community may prove helpful, as Peirce would most probably agree.

James's interpretation of Peirce's pragmatic maxim remains faithful until the last part of the last sentence, i.e., "so far as that conception has positive significance at all." Although James does not explain what he means by "positive significance," we could safely infer that the phrase may be interchangeable with "practical difference." It is at this point that James departs from Peirce. James and Peirce are different in two respects. First, by stressing the practical difference that a conception makes to you and me, James tries to reconcile pragmatism with metaphysics, and his objection to metaphysics is therefore moderate in comparison with Peirce's. Second, James seems to have introduced effects into a theory of truth in the way of emphasizing the cash value of a conception, which means that the value of a conception depends on what difference it makes to you and me. Thus, James diverges from Peirce who confines effects to a theory of meaning.

In "The Meaning of Truth,” James (2000) claims that his general notion of truth as working, either actual or conceivable, can be found in Dewey as well (285).

\section{Dewey and the Pragmatic Maxim}

Dewey was the most prominent pragmatist. Nevertheless, he used instrumentalism to distinguish his philosophy from James's pragmatism. He disagreed with James’s assessment that pragmatic principles were metaphysically neutral (Field 2007). But he acknowledged James’s influence on him.

Following James, Dewey affirms the pragmatic maxim, though implicitly (Burke 2007). Dewey holds in "The Development of American Pragmatism" that it is "not the origin of a concept, it is its application which becomes the criterion of its value; and here we have the whole of pragmatism in embryo" (Stuhr 2000, 433). The fundamental category of conception is then sustained by and in their value in application to concrete experiences (Stuhr 2000, 433). Application is a means of examining ideas. If Peirce examines ideas in terms of their practical bearings in order to make those ideas logically clear, then Dewey examines ideas in terms of their application in order to determine their value in our experience. In Dewey, as in James, action yields or establishes the truth of ideas (Stuhr 2000, 436). The test of the truth of ideas becomes, in Dewey's own words, "the ability to bring about certain changes" (Stuhr 2000, 436), that is to say, to solve problems.

For Dewey, a conception's consequences in action directed at problems are the measure of its success and its truth (Stuhr 2000, 436). In "The Pattern of Inquiry," Dewey (2000) interprets the pragmatic maxim as follows: "Ideas are anticipated consequences (forecasts) of what will happen when certain operations are executed under and with respect to observed conditions" (485). "Pragmatic" is otherwise reiterated (in Logic: The Theory of Inquiry) as: "namely the function of consequences as necessary tests of the validity of propositions, provided these consequences are operationally instituted and are such as to resolve the specific 
problem evoking the operations” (iv). Dewey's (2000) equation of ideas with consequences and actions is strengthened by his statement that ideas are operational: "Ideas are operational in that they instigate and direct further operations of observation” (487). Hence, Dewey reinforces an implication of the pragmatic maxim that is also recognized by James and Peirce, namely that if a thing or an idea is what it does, then knowledge can reliably proceed experimentally (Pratt 2002, 21).

\section{Mead and the Pragmatic Maxim}

In “Realism, Pragmatism, and Science,” Mead lends support to Dewey’s and James's interpretations of the pragmatic maxim in the way of making some amendments to their interpretations. At the beginning of his essay, Mead remarks: "Back of the work of both (James and Dewey) lies the common assumption of the testing of the truth of an idea, of a hypothesis, by its actual working” (Mead 2000, 598). This pragmatic doctrine, according to Mead (2000), has two sources (602). (Mead calls the pragmatic maxim "the pragmatic doctrine" which occurs frequently in the essay under discussion.) The first source is behavioristic psychology, which enables one to put intelligence in its proper place within the conduct of the form, and to state that intelligence in terms of the activity of the form itself (Mead 2000, 602). The second source is the research process, the scientific technique which comes back to the testing of a hypothesis by its working (Mead 2000, 602). The testing of a hypothesis by its working, which is one phase of the pragmatic doctrine, involves testing a hypothesis by its ability to continue a process which has been inhibited (Mead 2000, 601). This ability, in Mead's view, is what pragmatists mean by "satisfaction." Another phase of the pragmatic doctrine, also the most important phase, is to bring the process of knowing inside of the process of conduct (Mead 2000, 602). (In so doing, Mead establishes a relationship between the pragmatic doctrine and behavioristic psychology.) Knowledge is a part of conduct, which brings out the other phase of the pragmatic doctrine, i.e., (Dewey's) instrumentalism, which means that the selective attitude of an organism and reflective thought give us the tools we need to keep up our process of living (Mead 2000, 602).

To sum up: Mead (1981) sees the pragmatic doctrine as a logical generalization of the scientific method (334). This doctrine is nothing but an expression of the experimental method (Mead 2000, 603). The importance of this doctrine lies in the fact that it finds its test of the so-called true in hypotheses and in the working of these hypotheses (Mead 2000, 601). And working is a successful solution of a problem (Mead 2000, 606). This puts us in mind of Dewey.

\section{Conclusion}

In Peirce, James, Dewey and Mead, the pragmatic maxim does "essential philosophical work" (Burke 2007), though they state and interpret the pragmatic maxim in multiple ways. They build their philosophies upon the pragmatic maxim, which they put to different uses. Peirce's Pragmaticism clarifies confusing ideas by introducing action and effects into a theory of meaning (Noddings 2006, 25); James's pragmatism settles metaphysical disputes by bringing action and effects into a theory of truth (Noddings 2006, 25); Dewey's instrumentalism is intended to solve problem situations in the way of testing the applicability of suggested solutions in operations and through effects; Mead's pragmatism tries to reconstruct problem situations in such a manner that, once a working hypothesis is effectually employed, stopped conduct could continue. Pragmatists, however, need not hold that both the meaning and the truth of an idea are functions of its practical outcome both because an emphasis on action and consequences is not a necessary feature of pragmatism 
(consequentialists also stress consequences) and because the pragmatic maxim does not by itself rule out all forms of absolutism (Burke 2007). Nonetheless, pragmatists must adhere to some version of the pragmatic maxim (Burke 2007), as the four classical pragmatists do. The pragmatic maxim guides and constitutes a pragmatist.

\section{Works Cited}

Burke, T. What Is Pragmatism. January 15, 2007. <http://theblog.philosophytalk.org/2007/01/what_is_pragmat.html>.

Dewey, J. Logic: The Theory of Inquiry. New York: Henry Holt, 1938.

---. “The Pattern of Inquiry.” Ed. John J. Stuhr. Pragmatism and Classical American Philosophy. Oxford: Oxford UP, 2000. 482-91.

Field, R. “John Dewey.” The Internet Encyclopedia of Philosophy. 2007. <http://www.iep.utm.edu/d/dewey.htm>.

Goodman, R. "William James.” March 19, 2006. Stanford Encyclopedia of Philosophy. <http://plato.stanford.edu/entries/james/>. James, W. “The Meaning of Truth.” Pragmatism: A New Name for Some Old Ways of Thinking. Cambridge: Harvard UP, 2000. 167-352.

---. “What Pragmatism Means.” Ed. John J. Stuhr. Pragmatism and Classical American Philosophy. Oxford: Oxford UP, 2000. 193-202.

Mead, G. H. “A Pragmatic Theory of Truth.” Ed. Andrew J. Reck. Selected Writings: George Herbert Mead. Chicago: The U of Chicago P, 1981. 320-34.

---. “Realism, Pragmatism, and Science.” Ed. John J. Stuhr. Pragmatism and Classical American Philosophy. Oxford: Oxford UP, 2000. 598-606.

Noddings, N. Philosophy of Education. Boulder, Colorado: Westview, 2006.

Peirce, C. S. "How to Make Our Ideas Clear.” Ed. John J. Stuhr. Pragmatism and Classical American Philosophy. Oxford: Oxford UP, 2000. 77-97.

Pratt, S. L. Native Pragmatism: Rethinking the Roots of American Philosophy. Bloomington, IN: Indiana UP, 2002.

Scheffler, I. “John Dewey.” Four Pragmatists. New York: Humanities, 1974.

Stuhr, J. J. “Introduction to John Dewey.” Ed. John J. Stuhr. Pragmatism and Classical American Philosophy. Oxford: Oxford UP, 2000. 431-44. 